\title{
Impact assessment of nuclear power plant discharge on zooplankton abundance and distribution in coastal waters of Kalpakkam, India
}

\author{
A. L. Muthulakshmi ${ }^{1 *}$, Usha Natesan², Vincent A. Ferrer ${ }^{1}$, K. Deepthi $^{1}$, V. P. Venugopalan ${ }^{3}$ and S. V. Narasimhan ${ }^{4}$
}

\begin{abstract}
Background: Kalpakkam coastal area serves as fishing ground, influenced by anthropogenic effluents from its surrounding populations and backwaters.

Methods: The monthly abundance and distribution of zooplankton and some physico-chemical parameters were investigated in coastal waters near a nuclear power plant, Kalpakkam 2011. Zooplankton and surface water samples collected from three different locations (stations P1, P2 and P3) in the heated and non-heated parts of the coastal waters were analyzed using standard methods.

Results: Among all plankton genera in the cooling water, zooplankton was observed most sensitive group to entrainment-induced stress. Thirty genera were identified over the period of the investigation. Zooplankton population followed a trend as P1 > P3 > P2. A clear monthly variation and slight differences among stations were observed in terms of the zooplankton genera. The investigations revealed that changes in zooplankton genera across water bodies could be associated with differing temperature.

Conclusion: Our results clearly demonstrate that heated water discharge from the Madras Atomic Power Station has a negligible effect on zooplankton population at engineered canal near Plutonium Recycle Project (station P2). There is no impact on zooplankton population due to thermal effluent discharge into the coastal area (stations P1 and P3). Hence, further investigation is required to estimate the impact zone at either side during different seasons.
\end{abstract}

Keywords: Zooplankton, Physico-chemical parameters, Season, Kalpakkam, Nuclear power plant

\section{Introduction}

Water is a liquid compound and it covers $71 \%$ of the earth's surface in form of rivers, lake, and seas and is useful for survival of man, animals, and plants (CIAThe World Fact book: Central intelligence agency 2008-2009). Zooplanktonic organisms are one of the most important components of aquatic systems, which is used in the conversion of plant protein into animal protein (Terbiyik Kurt and Polat 2015). They are also used to construct the modern oceanic food webs and food source for larval fish and shrimp in natural water bodies (Damotharan et al. 2010). Coastal marine food

\footnotetext{
* Correspondence: almuthulakshmi@gmail.com

${ }^{1}$ Anna University, Chennai 600025, India

Full list of author information is available at the end of the article
}

web thus mainly activates in the presence of zooplankton. Zooplanktons are secondary producers that act as a central link with the primary producers, the phytoplankton and other organisms (Mitra et al. 2004). Compared to phytoplanktons, zooplanktons are larger and easier to identify and can act as valuable indicator of tropic status (Ward and Whipple 1966). In water pollution studies, few zooplankton species are used as "bioindicators" due to their occurrence, vitality, and responses. Prior to pollutants effect, bioindicators are useful in predicting the level and degree of the pollutants (Hao 1996; Ward and Whipple 1959).

In general, the ecological system and a measure of community pattern are described through plankton diversity. Noteworthy, seasonal changes control the 
diversity of plankton by the supply of plant nutrients (Magurran 1988; Barnese and Schelske 1994). Report from Baker and Hosny demonstrates the zooplankton diversity and abundance in coastal waters (Baker and Hosny 2005). Coastal zones located near to the nuclear and thermal power stations make use of large volumes of seawater for the cooling of generating units (Jahir Hussain et al. 2010). Consequently, marine life system gets affected by heated effluents from power plant which contains biofouling control agents. The thermal effluents thus significantly impact the food chain, which reflects directly or indirectly in the distribution and abundance of marine organisms. Also leads mechanical stress source to direct death of organisms and decrease in reproduction of zooplankton population (Kartasheva et al. 2008). Recently, numerous studies in anthropogenic impact, thermal discharges from power plant in to coastal waters, climate change, and modifications in biodiversity and biogeography are reported (Tseng et al. 2011).

Normally, the coastal environment is highly sensitive with great ecological and economic importance. It supports various communities and is directly or indirectly affected by anthropogenic activities (Cummins et al. 2004). It is known that the ocean and land margins are linked by coastal zones.
The human activities along estuarine and coastal waters enhance loading of huge volume of nutrient concentration that leads to environmental problems. The physicochemical parameters monthly influence the variation in plankton distribution, abundance, and species diversity (Raymond 1983; Ezra and Nwankwo 2001). Generally, the physico-chemical variables were affected by seasonal variations and human activities along water body which could impacts the phytoplankton and zooplankton population. As explained by Gislason et al. 2014, the large-scale hydrographical conditions affect the variation in copepod species composition. It is well evident from various studies that the spatiotemporal distribution and abundance of planktonic organisms and fish larvae are influenced by seasonal variations of salinity, temperature, oxygen, turbidity, and food resources (Blaber et al. 1997; Harris et al. 1999; Barletta-Bergan et al. 2002a, b; Hoffmeyer et al. 2009; Ooi and Chong 2011; Williams et al. 2012). Also, a study showed that fishery activities are influenced by human activities in the bay (Terbiyik Kurt and Polat 2013).

It is worth investigating the wastes introduced into coastal zones by human activities along Kalpakkam coast, which could also affect the physico-chemical variables thus causing variation in abundance and distribution of

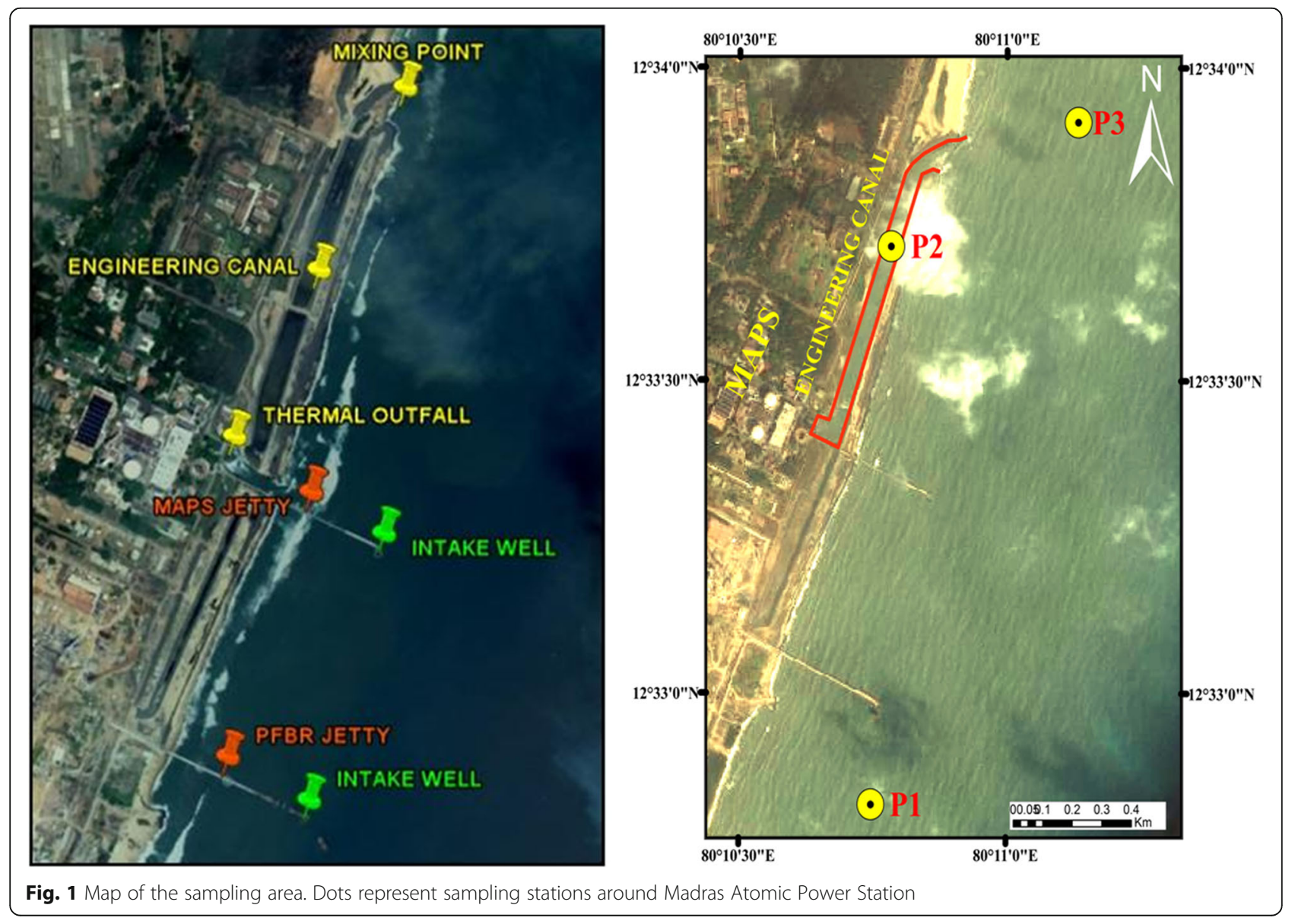


plankton. However, there is limited information on the monthly abundance and distribution of zooplankton as well as the water quality around thermal discharge locations near nuclear power plant, Kalpakkam. The present study attempts to provide evidence about zooplankton with water quality for future references.

\section{Materials and methods}

\section{Study area}

Kalpakkam coast $\left(12^{\circ} 33 \mathrm{~N}\right.$ and $\left.80^{\circ} 11 \mathrm{E}\right)$ is situated about $80 \mathrm{~km}$ south of the mega city Chennai. A nuclear power plant (Madras Atomic Power Station, MAPS) and a desalination plant are located at southeast coast of India. MAPS consists of two units of pressurized heavy water reactor, each of 235 MW (e) capacities. Unit-1 reactor went operational on 23 July, 1983, whereas unit-2 reactor went operational on 18 September, 1985. The two reactors use seawater at the rate of $35 \mathrm{~m}^{3} / \mathrm{s}$ for the purpose of cooling the condenser. After extracting the heat, the heated effluent is released into the sea. The temperature gradient across the cooling water system from intake to outfall varies depending upon the level of power production and it is approximately $7{ }^{\circ} \mathrm{C}$.

\section{Sampling stations}

Three sampling stations were chosen almost $2 \mathrm{~km}$ around the thermal power plant (Fig. 1). They were as follows:
Station 1: P1-200 m south of near Prototype Fast Breeder Reactor (PFBR)

Station 2: P2-Engineered Canal near Plutonium

Recycle Project (PRP)

Station 3: P3-Near MAPS Mixing Point

\section{Samples collection and analyses}

Surface water and zooplankton samples were collected from the three stations around thermal power plant monthly between January 2011 and December 2011 (Fig. 1). Zooplankton samples were collected at monthly intervals through horizontal surface tows (nearly 5$10 \mathrm{~m}$ depth) using a typical zooplankton net with $0.35 \mathrm{~m}$ diameter and $158 \mu \mathrm{m}$ mesh size and these samples were preserved in 5\% buffered formalin solution used for qualitative analysis. A known quantity of water $(50 \mathrm{~L})$ was filtered through a bagnet of same mesh size and numerical analysis was carried out using Sedgewick-Rafter cell under the microscope for the quantitative analysis (ICMAM 1998). The zooplanktons were identified according to standard references from Newell and Newell (1977), Todd and Laverack (1991), Perumal et al. (1998), and Conway et al. 2003. Surface water samples were collected for physico-chemical analysis from all three stations. Environmental parameters such as $\mathrm{pH}$, temperature, salinity, turbidity, suspended particulate matter (SPM), dissolved oxygen (DO), and chlorophyll- $a(\mathrm{Chl}-a)$ were analyzed according to standard
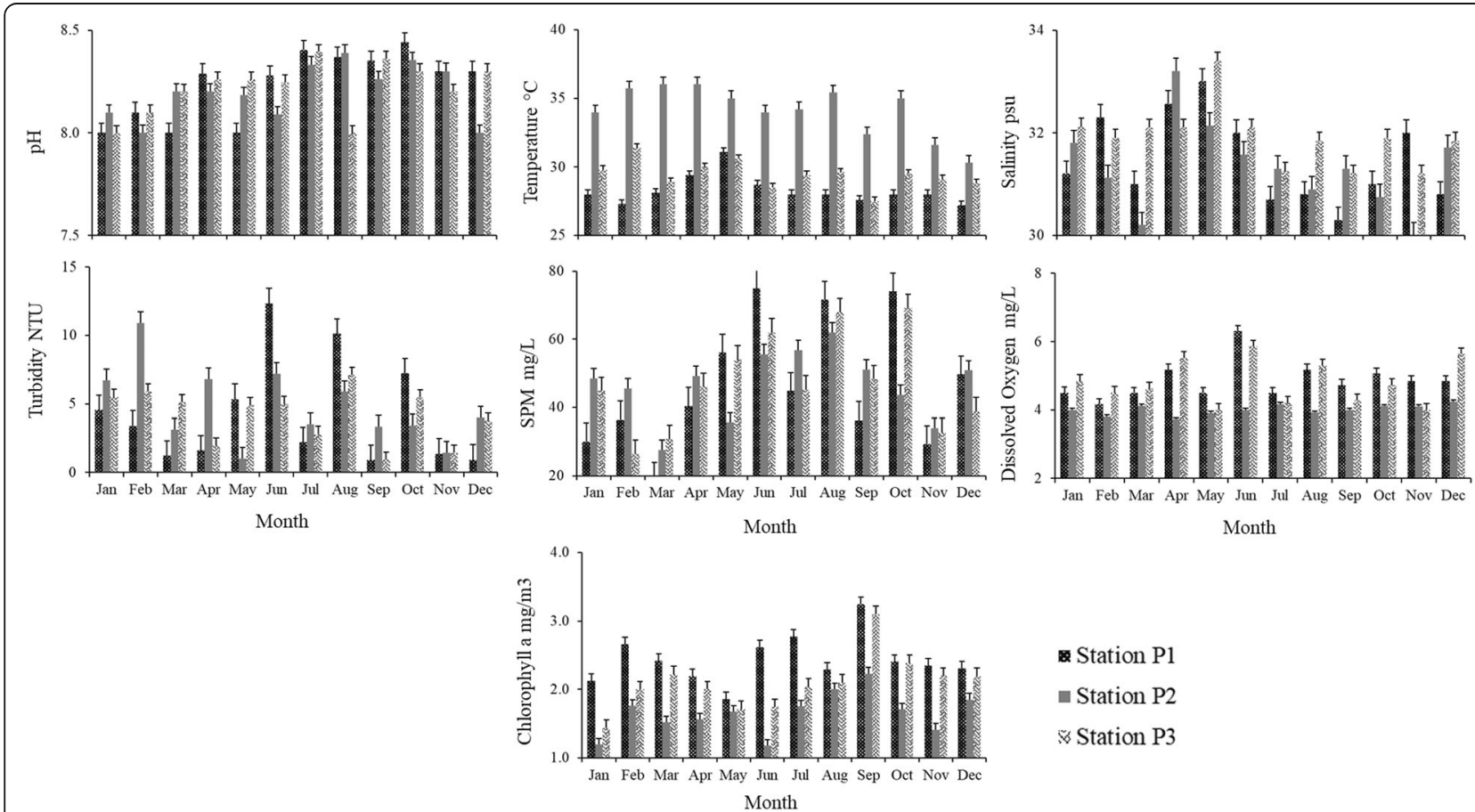

Station P1

- Station P2

$\approx$ Station P3

Fig. 2 Monthly variation of $\mathrm{pH}$, water temperature, salinity, turbidity, SPM, dissolved oxygen, and chlorophyll a in surface waters for the three stations of the Kalpakkam coast 
methods described by Strickland and Parsons (1972). A canonical correspondence analysis (CCA) (CANOCO for Windows 4.5) was performed to determine the statistical significance of the correlation between the environmental parameters and zooplankton (ter Braak and Smileuer 2002).

\section{Results and discussion}

\section{Environmental variables}

Hydrogen ion concentrations $(\mathrm{pH})$ in surface waters remain alkaline throughout the study period at three stations with the maximum during the northeast monsoon and the minimum during pre- and post-monsoons. High $\mathrm{pH}$ was recorded in summer at station P3; it might be due to the influence of seawater penetration and high biological activity (Govindasamy et al. 2000) and the occurrence of high photosynthetic activity (Saravanakumar et al. 2008). Surface water temperature was measured at station $\mathrm{P} 1, \mathrm{P} 2$, and $\mathrm{P} 3$; the values vary from 27.2 to $31.1{ }^{\circ} \mathrm{C}, 30.3$ to $36{ }^{\circ} \mathrm{C}$, and 27.5 to $31.4{ }^{\circ} \mathrm{C}$, respectively (Fig. 2). The sudden drop at station P3 mainly occurs due to the result of turbulent mixing of the sea. Highest temperature $\left(36{ }^{\circ} \mathrm{C}\right)$ is recorded in March and April and the lowest $\left(27.2{ }^{\circ} \mathrm{C}\right)$ in December. The lowest temperature is due to strong land sea breeze and precipitation and the highest value could be attributed to high solar radiation (Das et al. 2002; Govindasamy et al. 2000; Santhanam and Perumal 2003). Temperature at outfall during this study period is about $8.4-9.6{ }^{\circ} \mathrm{C}$ greater than that at the intake, when the two units are operational. A

Table 1 Monthly distribution of dominant zooplanktonic genera at station P1

\begin{tabular}{|c|c|c|c|c|c|c|c|c|c|c|c|c|c|}
\hline Genera & Genera No. & Jan & Feb & Mar & Apr & May & Jun & Jul & Aug & Sep & Oct & Nov & Dec \\
\hline Acartia & G1 & 3.0 & 3.0 & 3.0 & 4.0 & 4.0 & 2.0 & 3.0 & 3.0 & 2.0 & 3.0 & 2.0 & 3.0 \\
\hline Acrocalanus & G2 & 3.0 & 3.0 & 3.0 & 3.0 & 3.0 & 3.0 & 3.0 & 2.0 & 2.0 & 2.0 & 3.0 & 2.0 \\
\hline Branchious & G3 & 3.0 & 3.0 & 3.0 & 3.0 & 3.0 & 2.0 & 3.0 & 2.0 & 3.0 & 2.0 & 2.0 & 2.0 \\
\hline Canthocalanus & G4 & 3.0 & 3.0 & 3.0 & 4.0 & 4.0 & 2.0 & 3.0 & 3.0 & 3.0 & 2.0 & 2.0 & 2.0 \\
\hline Centerophages & G5 & 3.0 & 3.0 & 3.0 & 2.0 & 3.0 & 3.0 & 2.0 & 2.0 & 2.0 & 3.0 & 2.0 & 2.0 \\
\hline Copilia & G6 & 3.0 & 3.0 & 3.0 & 2.0 & 2.0 & 3.0 & 2.0 & 2.0 & 2.0 & 2.0 & 2.0 & 2.0 \\
\hline Corycaeus & G7 & 3.0 & 3.0 & 3.0 & 2.0 & 3.0 & 2.0 & 3.0 & 3.0 & 3.0 & 2.0 & 2.0 & 2.0 \\
\hline Diphyes & G8 & 2.0 & 2.0 & 2.0 & 2.0 & 2.0 & 2.0 & 2.0 & 3.0 & 2.0 & 2.0 & 2.0 & 2.0 \\
\hline Eucalanus & G9 & 3.0 & 3.0 & 3.0 & 4.0 & 4.0 & 3.0 & 3.0 & 3.0 & 3.0 & 3.0 & 2.0 & 2.0 \\
\hline Euterpina & G10 & 3.0 & 3.0 & 3.0 & 3.0 & 3.0 & 2.0 & 3.0 & 3.0 & 3.0 & 2.0 & 2.0 & 2.0 \\
\hline Evadne & G11 & 3.0 & 3.0 & 3.0 & 4.0 & 4.0 & 3.0 & 3.0 & 3.0 & 2.0 & 2.0 & 2.0 & 2.0 \\
\hline Favella & G12 & 3.0 & 3.0 & 3.0 & 3.0 & 3.0 & 2.0 & 2.0 & 3.0 & 3.0 & 2.0 & 2.0 & 2.0 \\
\hline Globigerina & G13 & 2.0 & 3.0 & 3.0 & 2.0 & 3.0 & 2.0 & 3.0 & 2.0 & 2.0 & 2.0 & 2.0 & 2.0 \\
\hline Labidocera & G14 & 2.0 & 3.0 & 2.0 & 3.0 & 3.0 & 3.0 & 2.0 & 3.0 & 3.0 & 2.0 & 2.0 & 2.0 \\
\hline Lucifer & G15 & 3.0 & 3.0 & 3.0 & 3.0 & 3.0 & 3.0 & 2.0 & 3.0 & 3.0 & 2.0 & 2.0 & 2.0 \\
\hline Macrosetella & G16 & 2.0 & 3.0 & 3.0 & 2.0 & 2.0 & 2.0 & 3.0 & 2.0 & 2.0 & 2.0 & 2.0 & 3.0 \\
\hline Microsetella & G17 & 2.0 & 2.0 & 3.0 & 2.0 & 2.0 & 2.0 & 2.0 & 3.0 & 2.0 & 2.0 & 2.0 & 2.0 \\
\hline Monostyla & G18 & 3.0 & 2.0 & 2.0 & 2.0 & 3.0 & 3.0 & 3.0 & 2.0 & 2.0 & 2.0 & 2.0 & 2.0 \\
\hline Oithona & G19 & 3.0 & 3.0 & 3.0 & 3.0 & 3.0 & 2.0 & 3.0 & 3.0 & 2.0 & 2.0 & 2.0 & 2.0 \\
\hline Oncacea & G20 & 3.0 & 3.0 & 3.0 & 3.0 & 3.0 & 2.0 & 3.0 & 2.0 & 2.0 & 2.0 & 2.0 & 2.0 \\
\hline Paracalanus & G21 & 3.0 & 3.0 & 3.0 & 4.0 & 4.0 & 3.0 & 3.0 & 3.0 & 3.0 & 2.0 & 2.0 & 2.0 \\
\hline Sagitta & $\mathrm{G} 22$ & 3.0 & 3.0 & 3.0 & 3.0 & 4.0 & 3.0 & 3.0 & 3.0 & 3.0 & 2.0 & 2.0 & 2.0 \\
\hline Temora & G23 & 3.0 & 3.0 & 3.0 & 4.0 & 4.0 & 2.0 & 2.0 & 2.0 & 3.0 & 2.0 & 2.0 & 2.0 \\
\hline Tintinnopsis & $\mathrm{G} 24$ & 3.0 & 3.0 & 4.0 & 4.0 & 4.0 & 3.0 & 3.0 & 3.0 & 3.0 & 2.0 & 2.0 & 2.0 \\
\hline Bivalve veliger larva & G25 & 2.0 & 2.0 & 3.0 & 3.0 & 3.0 & 2.0 & 2.0 & 2.0 & 2.0 & 2.0 & 2.0 & 2.0 \\
\hline Cirripede nauplii & G26 & 2.0 & 2.0 & 3.0 & 3.0 & 3.0 & 2.0 & 2.0 & 2.0 & 2.0 & 2.0 & 2.0 & 2.0 \\
\hline Crustacean naupilus & G27 & 2.0 & 3.0 & 3.0 & 3.0 & 3.0 & 2.0 & 2.0 & 2.0 & 3.0 & 2.0 & 2.0 & 2.0 \\
\hline Copepod naupilus & G28 & 3.0 & 3.0 & 3.0 & 3.0 & 2.0 & 2.0 & 2.0 & 2.0 & 3.0 & 2.0 & 2.0 & 2.0 \\
\hline Gastropod veliger & G29 & 3.0 & 3.0 & 3.0 & 3.0 & 3.0 & 2.0 & 2.0 & 2.0 & 2.0 & 2.0 & 2.0 & 2.0 \\
\hline Polycheate larve & G30 & 2.0 & 2.0 & 3.0 & 3.0 & 3.0 & 2.0 & 2.0 & 2.0 & 2.0 & 2.0 & 2.0 & 2.0 \\
\hline
\end{tabular}

$(1.0=$ rare; $2.0=$ frequent; $3.0=$ moderate; $4.0=$ high $)$ 
smaller $\Delta \mathrm{T}$ of $1.9-5.8^{\circ} \mathrm{C}$ (with respect to the intake point temperature) is recorded at the mixing point.

Salinity ranges from 30.0 to 33.4 PSU and is high during post monsoon and low during the northeast monsoon at three stations. Higher values could be attributed to the low amount of rainfall, higher rate of evaporation, and neritic water dominance (Asha and Diwakar 2007). Turbidity and SPM vary from 0.90 to $18.10 \mathrm{NTU}$ and 26.40 to $79.00 \mathrm{mg} / \mathrm{L}$ respectively. Station P2 records marginally higher turbidity compared to the others, which could be due to the occurrence of high turbulence owing to its closeness to MAPS outfall. Elevated dissolved oxygen levels are observed in June at station P1 and P3. Chl- $a$ concentration at station P1 and P3 is comparable (Fig. 2). The low Chl-a at station P2 than P1 may be attributable to grazing taking place inside the intake tunnel which is recovered at the mixing point.

\section{Zooplankton abundance and distribution}

The members of zooplankton recorded during the study are as follows: Ciliata, Foraminifera, Siphonophora, Cladocera, Rotifera, Copepoda, Harpacticoida, Cyclopoida, Poecilostomatoida, Decapoda, Chaetognatha, and larval plankton. Tables 1, 2, and 3 presented the genera compositions of zooplankton from all the three stations. A total of 24 genera (G) of zooplankton are identified along with six larval plankton which include two that belonged to Ciliata, one to foraminifera, one to Siphonophora, one to Cladocera, two to Rotifera, eight to

Table 2 Monthly distribution of dominant zooplanktonic genera at station P2

\begin{tabular}{|c|c|c|c|c|c|c|c|c|c|c|c|c|c|}
\hline Genera & Genera No. & Jan & Feb & Mar & Apr & May & Jun & Jul & Aug & Sep & Oct & Nov & Dec \\
\hline Acartia & G1 & 2.0 & 3.0 & 3.0 & 4.0 & 3.0 & 2.0 & 2.0 & 2.0 & 2.0 & 2.0 & 2.0 & 2.0 \\
\hline Acrocalanus & G2 & 2.0 & 2.0 & 3.0 & 3.0 & 3.0 & 2.0 & 2.0 & 2.0 & 2.0 & 2.0 & 2.0 & 2.0 \\
\hline Branchious & G3 & 2.0 & 2.0 & 3.0 & 2.0 & 3.0 & 1.0 & 1.0 & 1.0 & 2.0 & 1.0 & 2.0 & 2.0 \\
\hline Canthocalanus & G4 & 3.0 & 3.0 & 3.0 & 3.0 & 3.0 & 2.0 & 2.0 & 2.0 & 1.0 & 2.0 & 2.0 & 2.0 \\
\hline Centerophages & G5 & 2.0 & 2.0 & 3.0 & 2.0 & 2.0 & 2.0 & 2.0 & 2.0 & 2.0 & 2.0 & 2.0 & 2.0 \\
\hline Copilia & G6 & 2.0 & 2.0 & 2.0 & 2.0 & 2.0 & 2.0 & 1.0 & 2.0 & 1.0 & 2.0 & 2.0 & 2.0 \\
\hline Corycaeus & G7 & 2.0 & 2.0 & 2.0 & 2.0 & 2.0 & 2.0 & 2.0 & 2.0 & 1.0 & 2.0 & 2.0 & 2.0 \\
\hline Diphyes & G8 & 2.0 & 2.0 & 2.0 & 2.0 & 2.0 & 1.0 & 2.0 & 2.0 & 1.0 & 2.0 & 2.0 & 1.0 \\
\hline Eucalanus & G9 & 2.0 & 2.0 & 2.0 & 3.0 & 2.0 & 2.0 & 2.0 & 2.0 & 1.0 & 2.0 & 1.0 & 2.0 \\
\hline Euterpina & G10 & 2.0 & 2.0 & 2.0 & 3.0 & 2.0 & 2.0 & 2.0 & 2.0 & 1.0 & 2.0 & 2.0 & 2.0 \\
\hline Evadne & G11 & 3.0 & 3.0 & 2.0 & 4.0 & 4.0 & 2.0 & 2.0 & 2.0 & 2.0 & 2.0 & 1.0 & 2.0 \\
\hline Favella & G12 & 2.0 & 2.0 & 2.0 & 2.0 & 3.0 & 1.0 & 1.0 & 2.0 & 2.0 & 2.0 & 2.0 & 2.0 \\
\hline Globigerina & G13 & 2.0 & 2.0 & 2.0 & 2.0 & 2.0 & 1.0 & 2.0 & 1.0 & 1.0 & 1.0 & 1.0 & 2.0 \\
\hline Labidocera & G14 & 2.0 & 2.0 & 2.0 & 2.0 & 2.0 & 2.0 & 2.0 & 2.0 & 2.0 & 2.0 & 2.0 & 2.0 \\
\hline Lucifer & G15 & 2.0 & 2.0 & 2.0 & 2.0 & 2.0 & 2.0 & 1.0 & 2.0 & 1.0 & 2.0 & 2.0 & 2.0 \\
\hline Macrosetella & G16 & 2.0 & 2.0 & 2.0 & 2.0 & 2.0 & 2.0 & 2.0 & 2.0 & 1.0 & 1.0 & 2.0 & 2.0 \\
\hline Microsetella & G17 & 2.0 & 2.0 & 2.0 & 2.0 & 2.0 & 2.0 & 2.0 & 1.0 & 1.0 & 1.0 & 2.0 & 2.0 \\
\hline Monostyla & G18 & 2.0 & 2.0 & 2.0 & 2.0 & 2.0 & 2.0 & 2.0 & 1.0 & 1.0 & 1.0 & 2.0 & 2.0 \\
\hline Oithona & G19 & 2.0 & 2.0 & 2.0 & 2.0 & 2.0 & 2.0 & 2.0 & 2.0 & 1.0 & 1.0 & 1.0 & 2.0 \\
\hline Oncacea & G20 & 2.0 & 2.0 & 2.0 & 2.0 & 3.0 & 1.0 & 1.0 & 1.0 & 1.0 & 1.0 & 1.0 & 1.0 \\
\hline Paracalanus & G21 & 2.0 & 3.0 & 2.0 & 2.0 & 3.0 & 2.0 & 2.0 & 2.0 & 2.0 & 1.0 & 2.0 & 1.0 \\
\hline Sagitta & $\mathrm{G} 22$ & 2.0 & 2.0 & 2.0 & 3.0 & 2.0 & 2.0 & 2.0 & 2.0 & 2.0 & 1.0 & 1.0 & 2.0 \\
\hline Temora & G23 & 2.0 & 2.0 & 2.0 & 3.0 & 3.0 & 1.0 & 1.0 & 1.0 & 1.0 & 1.0 & 1.0 & 2.0 \\
\hline Tintinnopsis & $\mathrm{G} 24$ & 2.0 & 2.0 & 2.0 & 4.0 & 4.0 & 1.0 & 2.0 & 2.0 & 2.0 & 1.0 & 1.0 & 2.0 \\
\hline Bivalve veliger larva & G25 & 2.0 & 2.0 & 3.0 & 3.0 & 3.0 & 2.0 & 1.0 & 2.0 & 2.0 & 2.0 & 2.0 & 2.0 \\
\hline Cirripede nauplii & G26 & 2.0 & 2.0 & 2.0 & 3.0 & 2.0 & 2.0 & 2.0 & 2.0 & 2.0 & 2.0 & 3.0 & 2.0 \\
\hline Crustacean naupilus & G27 & 2.0 & 2.0 & 2.0 & 3.0 & 2.0 & 2.0 & 2.0 & 2.0 & 2.0 & 2.0 & 3.0 & 2.0 \\
\hline Copepod naupilus & G28 & 2.0 & 2.0 & 2.0 & 2.0 & 3.0 & 2.0 & 2.0 & 2.0 & 2.0 & 3.0 & 2.0 & 2.0 \\
\hline Gastropod veliger & G29 & 2.0 & 2.0 & 2.0 & 2.0 & 2.0 & 2.0 & 2.0 & 2.0 & 2.0 & 2.0 & 2.0 & 2.0 \\
\hline Polycheate larve & G30 & 2.0 & 2.0 & 2.0 & 2.0 & 2.0 & 2.0 & 2.0 & 2.0 & 2.0 & 2.0 & 2.0 & 2.0 \\
\hline
\end{tabular}

$(1.0=$ rare; 2.0 = frequent; $3.0=$ moderate; $4.0=$ high $)$ 
Table 3 Monthly distribution of dominant zooplanktonic genera at station P3

\begin{tabular}{|c|c|c|c|c|c|c|c|c|c|c|c|c|c|}
\hline Genera & Genera No. & Jan & Feb & Mar & Apr & May & Jun & Jul & Aug & Sep & Oct & Nov & Dec \\
\hline Acartia & G1 & 3.0 & 3.0 & 3.0 & 3.0 & 3.0 & 2.0 & 3.0 & 2.0 & 2.0 & 3.0 & 2.0 & 2.0 \\
\hline Acrocalanus & G2 & 3.0 & 2.0 & 3.0 & 3.0 & 3.0 & 2.0 & 2.0 & 2.0 & 2.0 & 2.0 & 2.0 & 2.0 \\
\hline Branchious & G3 & 2.0 & 3.0 & 3.0 & 2.0 & 2.0 & 2.0 & 3.0 & 2.0 & 3.0 & 2.0 & 2.0 & 2.0 \\
\hline Canthocalanus & G4 & 3.0 & 3.0 & 3.0 & 3.0 & 3.0 & 2.0 & 3.0 & 3.0 & 3.0 & 2.0 & 2.0 & 2.0 \\
\hline Centerophages & G5 & 3.0 & 2.0 & 3.0 & 2.0 & 2.0 & 3.0 & 2.0 & 2.0 & 2.0 & 3.0 & 2.0 & 2.0 \\
\hline Copilia & G6 & 2.0 & 2.0 & 3.0 & 2.0 & 2.0 & 3.0 & 2.0 & 2.0 & 2.0 & 2.0 & 2.0 & 2.0 \\
\hline Corycaeus & G7 & 2.0 & 3.0 & 3.0 & 2.0 & 2.0 & 2.0 & 3.0 & 3.0 & 3.0 & 2.0 & 2.0 & 2.0 \\
\hline Diphyes & G8 & 2.0 & 2.0 & 2.0 & 3.0 & 2.0 & 2.0 & 2.0 & 3.0 & 2.0 & 2.0 & 2.0 & 2.0 \\
\hline Eucalanus & G9 & 3.0 & 3.0 & 3.0 & 3.0 & 4.0 & 3.0 & 2.0 & 3.0 & 2.0 & 3.0 & 2.0 & 2.0 \\
\hline Euterpina & G10 & 2.0 & 3.0 & 3.0 & 3.0 & 2.0 & 2.0 & 3.0 & 3.0 & 3.0 & 2.0 & 2.0 & 2.0 \\
\hline Evadne & G11 & 3.0 & 3.0 & 3.0 & 3.0 & 4.0 & 3.0 & 2.0 & 3.0 & 2.0 & 2.0 & 2.0 & 2.0 \\
\hline Favella & G12 & 2.0 & 2.0 & 3.0 & 3.0 & 3.0 & 2.0 & 2.0 & 3.0 & 3.0 & 2.0 & 2.0 & 2.0 \\
\hline Globigerina & G13 & 2.0 & 2.0 & 3.0 & 2.0 & 2.0 & 2.0 & 3.0 & 2.0 & 2.0 & 2.0 & 2.0 & 2.0 \\
\hline Labidocera & G14 & 2.0 & 3.0 & 2.0 & 3.0 & 3.0 & 3.0 & 2.0 & 3.0 & 2.0 & 2.0 & 2.0 & 2.0 \\
\hline Lucifer & G15 & 3.0 & 2.0 & 3.0 & 3.0 & 3.0 & 3.0 & 2.0 & 3.0 & 3.0 & 2.0 & 2.0 & 2.0 \\
\hline Macrosetella & G16 & 2.0 & 3.0 & 3.0 & 2.0 & 2.0 & 2.0 & 3.0 & 2.0 & 2.0 & 2.0 & 2.0 & 2.0 \\
\hline Microsetella & G17 & 2.0 & 2.0 & 2.0 & 2.0 & 2.0 & 2.0 & 2.0 & 3.0 & 2.0 & 2.0 & 2.0 & 2.0 \\
\hline Monostyla & G18 & 2.0 & 2.0 & 2.0 & 2.0 & 2.0 & 3.0 & 2.0 & 2.0 & 2.0 & 2.0 & 2.0 & 2.0 \\
\hline Oithona & G19 & 3.0 & 2.0 & 2.0 & 2.0 & 3.0 & 2.0 & 3.0 & 3.0 & 2.0 & 2.0 & 2.0 & 2.0 \\
\hline Oncacea & $\mathrm{G} 20$ & 3.0 & 3.0 & 2.0 & 3.0 & 3.0 & 2.0 & 2.0 & 2.0 & 2.0 & 2.0 & 2.0 & 2.0 \\
\hline Paracalanus & G21 & 3.0 & 3.0 & 3.0 & 3.0 & 3.0 & 3.0 & 2.0 & 3.0 & 3.0 & 2.0 & 2.0 & 2.0 \\
\hline Sagitta & $\mathrm{G} 22$ & 3.0 & 3.0 & 2.0 & 3.0 & 3.0 & 2.0 & 3.0 & 3.0 & 3.0 & 2.0 & 2.0 & 2.0 \\
\hline Temora & G23 & 2.0 & 2.0 & 3.0 & 3.0 & 4.0 & 2.0 & 2.0 & 2.0 & 3.0 & 2.0 & 2.0 & 2.0 \\
\hline Tintinnopsis & $\mathrm{G} 24$ & 2.0 & 3.0 & 3.0 & 3.0 & 4.0 & 3.0 & 3.0 & 3.0 & 3.0 & 2.0 & 2.0 & 2.0 \\
\hline Bivalve veliger larva & G25 & 2.0 & 2.0 & 3.0 & 3.0 & 3.0 & 2.0 & 2.0 & 2.0 & 2.0 & 2.0 & 2.0 & 2.0 \\
\hline Cirripede nauplii & G26 & 2.0 & 2.0 & 3.0 & 3.0 & 3.0 & 2.0 & 2.0 & 2.0 & 2.0 & 2.0 & 2.0 & 2.0 \\
\hline Crustacean naupilus & G27 & 2.0 & 2.0 & 2.0 & 3.0 & 3.0 & 2.0 & 2.0 & 2.0 & 2.0 & 2.0 & 2.0 & 2.0 \\
\hline Copepod naupilus & $\mathrm{G} 28$ & 2.0 & 2.0 & 3.0 & 3.0 & 2.0 & 2.0 & 2.0 & 1.0 & 2.0 & 2.0 & 2.0 & 2.0 \\
\hline Gastropod veliger & G29 & 2.0 & 2.0 & 2.0 & 2.0 & 2.0 & 2.0 & 2.0 & 2.0 & 2.0 & 2.0 & 2.0 & 2.0 \\
\hline Polycheate larve & G30 & 2.0 & 2.0 & 3.0 & 2.0 & 2.0 & 2.0 & 2.0 & 2.0 & 2.0 & 2.0 & 2.0 & 2.0 \\
\hline
\end{tabular}

$(1.0=$ rare; $2.0=$ frequent; $3.0=$ moderate; $4.0=$ high $)$

Copepoda, three to Harpacticoida, one to Cyclopoida, three to Poecilostomatoida, one to Decapoda, one to Chaetognatha, and also six larvae (Tables 1, 2, and 3).

Numerically, zooplankton genera count at three locations vary as $423-771$ cells $/ \mathrm{ml}$ (P1), 354-632 cells/ $\mathrm{ml}$ (P2), and 414-754 cells/ml (P3). On the whole, copepods contribute the dominant population and the order of various groups are copepoda > larvae plankton $>$ Harpacticoida and Poicilostomatoida $>$ Rotifera and Ciliata > Foraminifera, Siphonophora, Cladocera, Cyclopoida, Decapoda, and Chaetognatha. The warm water discharged by the power plant increases the temperature of the surrounding sea water causing physiological stress; on the other hand, it also acts as physical forcing by modulating the direction of the water current. So, the discharge from MAPS not only exerts temperature stress on copepods but also influences the distribution pattern by changing the direction of the water currents.

Calanoid copepods absolutely dominate the copepod abundance throughout a year. Although the smallbody-sized genus, Paracalanus, are dominant in all stations, the composition of calanoid communities is different between the sites and is almost three times higher at station P1 (Table 1). Copepod genus throughout the study period is similar in station P1 and station P3 with the dominance of Paracalanus, Temora, and Acartia. Large calanoid copepods including Canthocalanus and Eucalanus are often abundant at station P1, but they are rarely found at station P2. In station P3, both Paracalanus 
and Temora dominate, whereas copepod community is present throughout the study period. Similar observation on copepods abundance was recorded by Santhanam and Perumal 2003 and Damotharan et al. 2010. Abundance of zooplankton fluctuates in accordance with salinity regime in the Kalpakkam coastal area. However, in all stations, rotifers are rarely found, although their occurrence is seasonal. The fish larvae were commonly found in all stations. This presence shows that the environment is suitable for a breeding and acts as nursery for a variety of fishes in coastal ecosystem (Damotharan et al. 2010). According to Townsend et al. (2000) and Miller (2005), plankton communities assist as a base for the food web chain that supports the commercial fisheries. The stable environmental condition and presence of neritic element that prevails higher zooplankton density during summer (Padmavati and Goswami 1996). Low population density is observed in northeast monsoon due to the hydrographically washable condition.

Presence of Tintinnopsis proves a salinity tolerance and the recorded higher density in summer might be due to the influence of neritic waters. Acrocalanus and
Paracalanus are common forms found in all stations which might be due to their ability to adapt to the prevailing environmental conditions. Evadne is abundant at station P2, perhaps due to its thermal tolerance. Crustacean larvae occur very sparsely at all the stations. The absence of crustacean larvae indicates that the area is not a rich habitat for shrimps in the coastal area. In terms of population, station P1 (PFBR) is the richest zone followed by station P3 (Near MAPS mixing point) and station P2 (PRP outfall). Abundance of zooplankton in the Kalpakkam coast is the highest during summer and the lowest during the northeast monsoon.

\section{Influence of the environmental variables on zooplankton} CCA performed on the basis of their Dominant Index $(Y)$ reveals the influence of genus-environmental variables and genus-month wise in all three stations. In this procedure, the environmental variables appear from the origin of the ordination as vectors. The importance of relationship between the environmental variable with
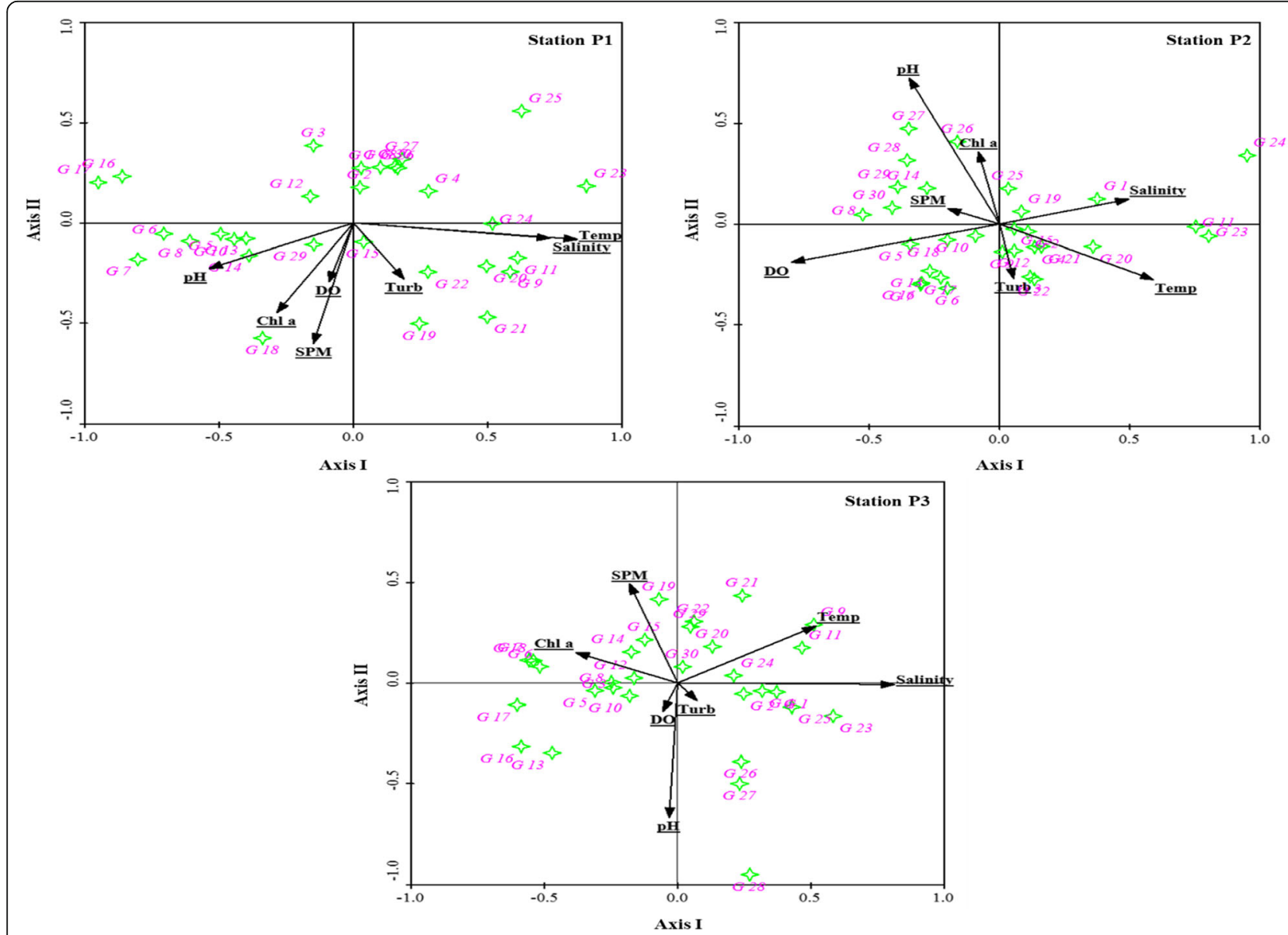

Fig. 3 Canonical correspondence analysis (CCA) for the ecological correlations between zooplankton genus and the environmental variables 
zooplankton genus and month was based on length of the vector represents.

In station P1, the second axis exposes that Lucifer is affected by turbidity. Temperature and salinity act as controlling factor for zooplankton; Evadns, Eucalanus, and Oncacea prefer high temperature and salinity. The plankton abundance and distribution are affected by seasonal variations of some physico-chemical parameters (Ezra and Nwankwo 2001). Labidocera and Gastropod veliger relies on pH (Fig. 3). Station P2 CCA plot (Fig. 3), Acartia and Oithona is influenced by salinity. Acrocaranus, Canthocalanus, Lucifer, Oncacea, and Paracalanus are affected by the temperature, while Eucalanus and Favella are sensitive to turbidity. Centerophages, Euterpina, and Monostyla exist in high DO concentration. Cirripede nauplii and Crustacean naupilus are mostly associated with high $\mathrm{pH}$. Eucalanus, Evadns, and Tintinnopsis are affected by temperature, while salinity presents as orthogonal in axis. Favella and Lucifer are affected by Chl- $a$ and SPM in station P3. The present observations prove that changes in zooplankton community in all stations might be associated with salinity.
The southwest monsoon influences the environmental variables such as $\mathrm{pH}, \mathrm{SPM}, \mathrm{Chl}-a$, and DO in station P1. The fourth axis separates temperature, turbidity, and salinity, and most of the collections were in post monsoon and northeast monsoon (Fig. 4). According to the fourth axis in station P2, the only environmental factor is Chl- $a$ which is mostly influenced by southwest monsoon, whereas SPM falls orthogonal. In station 3, first axis divides temperature with turbidity and most of these groups fall into the northeast monsoon. The second axis separates with $\mathrm{pH}, \mathrm{SPM}$, and DO were influenced by southwest monsoon. Salinity forms the third axis, its impact in late post monsoon and loosely related with January and March. Accord to ecological systems, the above comparisons highlight that the seasonal fluctuation of environmental variables may affect the zooplankton species (Drake and Arias 1991; Strydom 2003; Potter et al. 2015).

\section{Conclusion}

Based on the present observation, the study has proved that Kalpakkam coastal waters are relatively unpolluted

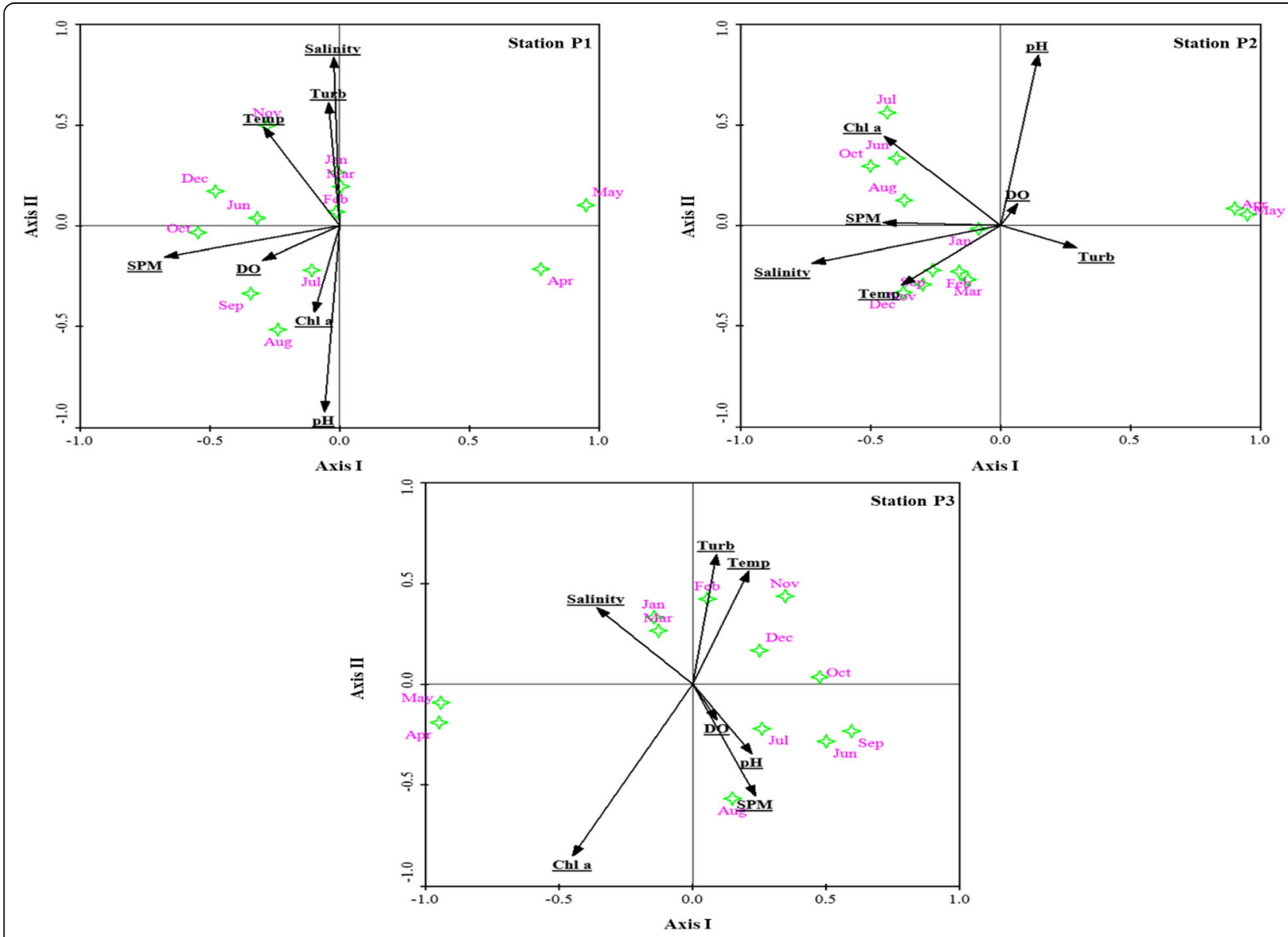

Fig. 4 Canonical correspondence analysis (CCA) for the ecological correlations between month wise zooplankton genus and the environmental variables 
with rich zooplankton diversity and enough physicochemical status to support plankton population. The abundance of zooplankton in the coastal waters of Kalpakkam is influenced by three factors: water movements, fish predation, and heating by the power station. Our data showed a clear pattern of zooplankton distribution with an increase in temperature and distance from the outfall to mixing zone. Over the study period, G1 to G30 zooplankton genera were recorded at all stations and also found that fluctuation from station to station. Distribution of genera is intermittently presented in the station P2 due to thermal effluent discharged through engineered canal. Data from field studies suggest that distribution of zooplankton population is dependent on thermal stress around the cooling water discharge, whereas station P1 was unaffected zone. The environmental factors can influence the distribution of zooplankton. The relationship between zooplankton genera and environmental parameters varied according to the genera and seasonal cycle. Temperature and salinity are the key factors influencing the distribution and abundance of zooplankton. Present knowledge on impact of MAPS effluents on marine life is sketchy; hence, further in-depth investigation is required to estimate the impact zone at either side during different seasons. This observation is used as basic information of the zooplankton distribution and abundance for further ecological assessment and monitoring of these coastal ecosystems.

\section{Abbreviations}

CCA: Canonical correspondence analysis; Chl-a: Chlorophyll-a; DO: Dissolved oxygen; G: Genera; ICMAM: Integrated coastal and marine area management; MAPS: Madras Atomic Power Station; MW (e): Megawatt electrical; P1, P2 and P3: Station name; PFBR: Prototype Fast Breeder Reactor; $\mathrm{pH}$ : Hydrogen ion concentrations; PRP: Plutonium Recycle Project; SPM: Suspended particulate matter; Y: Dominant index

\section{Acknowledgements}

The authors would like to thank the Board for Research in Nuclear Sciences for their financial support for this research. The corresponding author also warmly thank to anonymous supervisor for editing the earlier version of the manuscript which helped much to improve the final version. The field staff members in this research deserve warm acknowledgments. We also thank the editor-in chief of Ecological Processes and the two anonymous reviewers whose comments helped much to improve the manuscript.

\section{Funding}

The authors would like to forward their gratitude to the Board for Research in Nuclear Sciences, Government of India for all sources of funding that helped the design of the study, field data collection, analyses, interpretation of the data, and writing the manuscript.

Availability of data and materials

Please contact the corresponding author for data requests.

\section{Authors' contributions}

Anna University and IGCAR designed and conducted the field research, analyzed the data, and interpreted the results and helped in writing the manuscript. All authors read and approved the final manuscript.

Ethics approval and consent to participate

Not applicable in this section.
Consent for publication

Not applicable in this section.

\section{Competing interests}

The authors declare that they have no competing interests.

\section{Publisher's Note}

Springer Nature remains neutral with regard to jurisdictional claims in published maps and institutional affiliations.

\section{Author details}

${ }^{1}$ Anna University, Chennai 600025, India. ${ }^{2}$ All India Council for Technical Education, Nelson Mandela Marg, Vasanth Kunj, New Delhi 110067, India. ${ }^{3}$ Nuclear Agriculture \& Biotechnology Division, Bhabha Atomic Research Centre, Trombay, Mumbai 400085, India. ${ }^{4}$ Chemistry Group, Water and Steam Chemistry Division, Bhabha Atomic Research Centre, Kalpakkam 603102, India.

Received: 13 February 2019 Accepted: 2 May 2019

Published online: 10 June 2019

\section{References}

Asha PS, Diwakar R (2007) Hydrobiology of the inshore waters off Tuticorin in the Gulf. J Marine Biol Assoc India 49:7-1

Baker M, Hosny CFH (2005) Zooplankton diversity and abundance in half moon bay, Saudi coastal waters, Arabian gulf. Sci J King Faisal Univ Basic Applied Sci 6:1-30

Barletta-Bergan A, Barletta M, Saint-Paul U (2002a) Community structure and temporal variability of ichthyoplankton in north Brazilian mangrove creeks. J Fish Biol 61:33-51

Barletta-Bergan A, Barletta M, Saint-Paul U (2002b) Structure and seasonal dynamics of larval fish in the Caete River estuary in North Brazil. Estuar Coast Shelf Sci 54:193-206

Barnese LE, Schelske CL (1994) Effects of nitrogen, phosphorus and carbon enrichment on planktonic and periphytic algae in a soft water, oligotrophic lake in Florida, USA. Hydrobiologia 277:159-170

Blaber SJM, Farmer MJ, Milton DA, Pangm J, Boon-Teck O, Wong P (1997) The ichthyoplankton of selected estuaries in Sarawak and Sabah: composition, distribution and habitat affinities. Estuar Coast Shelf Sci 45:197-208

CIA - The World Fact book: Central intelligence agency. Retrieved 2008-2009, 12-20

Conway DVP, White RG, Hugues-Dit-Ciles J, Gallienne CP, Robins DB (2003) Guide to the coastal and surface zooplankton of the south-western Indian ocean, DEFRA Darwin initiative zooplankton programme, version 1 June 2003. Marine Biological Association of the United Kingdom Occasional Publication No. 15

Cummins SP, Roberts DE, Ajani P, Underwood AJ (2004) Comparisons of assemblages of phytoplankton between open and seagrass habitats in a shallow coastal lagoon. Mar Freshw Res 55:447-456

Damotharan P, Vengadesh Perumal N, Arumugam M, Perumal P, Vijayalakshmi S, Balasubramanian T (2010) Studies on zooplankton ecology from Kodiakkarai (point calimere) coastal waters (south east coast of India). Res J Biol Sci 5(2): 187-198

Das I, Mohan M, Krishnamoorthy K (2002) Detection of marine aerosols with IRSP4 ocean colour monitor. Proc Indian Acad Sci 111:425-435

Drake P, Arias AM (1991) Composition and seasonal fluctuations of the ichthyoplankton community in a shallow tidal channel of Cadiz bay (S.W. Spain). J Fish Biol 39:245-263

Ezra AG, Nwankwo DI (2001) Composition of phytoplankton algae in Gubi reservoir, Bauchi, Nigeria. J Aquat Sci 16(2):115-118

Gislason A, Petursdottir H, Gudmundsson K (2014) Long-term changes in abundance of Calanus finmarchicus south and north of Iceland in relation to environmental conditions and regional diversity in spring 1990-2013. ICES J Mar Sci 71:2539-2549

Govindasamy C, Kannan L, Azariah J (2000) Seasonal variation in physicochemical properties and primary production in the coastal water biotopes of Coromandel coast, India. J Environ Biol 21:1-7

Hao OJ (1996) Bioindicators for water quality evaluation—a review. J Chinese Institute Environ Eng 6(1):1-19

Harris SA, Cyrus DP, Beckeley LE (1999) The larval fish assemblage in nearshore coastal waters off the St Lucia estuary, South Africa. Estuar Coast Shelf Sci 49: 789-811 
Hoffmeyer MS, Menendez MC, Biancalana F, Nizovoy AM, Torres ER (2009) Ichthyoplankton spatial pattern in the inner shelf off Bahía Blanca estuary, SW Atlantic Ocean. Estuar Coast Shelf Sci 84:383-392

ICMAM (1998) Manual on methodology for biological parameters. Department of Ocean Development, ICMAM Project Directorate, Chennai, pp 27-121

Jahir Hussain K, Mohanty AK, Satpathy KK, Prasad MVR (2010) Abundance pattern of wedge clam Donax cuneatus (L.) in different spatial scale in the vicinity of a coastal nuclear power plant. Environ Monit Assess 163:185-194

Kartasheva NV, Fomin DV, Popov AV, Kuchkina MA, Minin DV (2008) Impact assessment of nuclear and thermal power plants on zooplankton in cooling ponds. Mosc Univ Biol Sci Bull 63(3):118-122

Kurt TT, Polat S (2015) Zooplankton abundance, biomass, and size structure in the coastal waters of the northeastern Mediterranean Sea. Turkish J Zoology 39:378-387

Magurran AE (1988) Ecological diversity and its measurement. Princeton University Press, Princeton, p 179

Miller TG (2005) The flow of energy: primary production to higher trophic levels. [online] Available: https://globalchange.umich.edu/globalchange1/current/ lectures/kling/energyflow/energyflow.html. [2017, 20 October]

Mitra A, Banerjee K, Gangopadyay A (2004) Introduction to marineplankton. Daya Publishing House, Delhi, p 6

Newell GE, Newell RC (1977) Marine plankton: a practical guide. 5th edn. Hutchinson and Co. Ltd, London, p 244

Ooi AL, Chong VC (2011) Larval fish assemblages in a tropical mangrove estuary and adjacent coastal waters: offshore-inshore flux of marine and estuarine species. Cont Shelf Res 31:1599-1610

Padmavati G, Goswami C (1996) Zooplankton ecology in the Mandovi-Zuari estuarine system of Goa, westcoast of India. Indian J Mar Sci 25:268-273

Perumal P, Sampathkumar P, Santhanam P (1998) Zooplankton of Parangipettai coastal waters. Monogr series. Vol. I. UGC-SAP, CAS in marine biology. Annamalai University, Paragipettai, p 31

Potter IC, Tweedley JR, Elliott M, Whitfield AK (2015) The ways in which fish use estuaries: a refinement and expansion of the guild approach. Fish Fish 16: 230-239

Raymond JEG (1983) Plankton and productivity in the oceans. In: Zooplankton, 2nd edn. Pergamon Press, Oxford, p 824

Santhanam P, Perumal P (2003) Diversity of zooplankton in Parangipettai coastal waters, southeast coast of India. J Mar boil Ass India 45(2):144-151

Saravanakumar A, Rajkumar M, Thivakaran GA (2008) Abundance and seasonal variations of phytoplankton in the creek waters of western mangrove of Kachchh-Gujarat. J Environ Biol 29:271-274

Strickland JDH, Parsons TR (1972) A practical hand book of seawater analyses, 2nd edn. Fisheries Research Board of Canada, Ottawa, p 310

Strydom NA (2003) An assessment of habitat use by larval fishes in a warm temperate estuarine creek using light traps. Estuaries 26:1310-1318

ter Braak CJF, Smileuer P (2002) CANOCO reference manual and CanoDraw for windows user's guide: software for canonical community ordination (version 4.5). Microcomputer power, Ithaca

Terbiyik Kurt T, Polat S (2013) Seasonal distribution of coastal mesozooplankton community in relation to the environmental factors in İskenderun bay (north-east Levantine, Mediterranean Sea). J Mar Biol Assoc UK 93:1163-1174

Todd CD, Laverack MS (1991) Coastal marine zooplankton-a practical manual for students. Cambridge University Press, Cambridge

Townsend CR, Harper JL, Begon M (2000) Essentials of ecology 3rd edn. Lackwell Science Publishers, London

Tseng L-C, Kumar R, Chen Q-C, Hwang J-S (2011) Faunal shift between two copepod congeners ( Temora discaudata and T. turbinata) in the vicinity of two nuclear power plants in southern East China Sea: spatiotemporal patterns of population trajectories over a decade. Hydrobiologia 666:301-315

Ward HB, Whipple GC (1959) Fresh-water biology 2nd edn. Wiley, New York

Ward HB, Whipple GC (1966) In: Edmondson WT (ed) fresh water biology, 2nd edn. Wiley, New York

Williams J, Hindell JS, Swearer SE, Jenkins GP (2012) Influence of freshwater flows on the distribution of eggs and larvae of black bream Acanthopagrus butcheri within a drought-affected estuary. J Fish Biol 80:2281-2301

\section{Submit your manuscript to a SpringerOpen ${ }^{\circ}$ journal and benefit from:}

- Convenient online submission

- Rigorous peer review

- Open access: articles freely available online

- High visibility within the field

- Retaining the copyright to your article

Submit your next manuscript at $\boldsymbol{\nabla}$ springeropen.com 